\title{
Non-Profit Corporation
}

National Cancer Institute

\section{Source}

National Cancer Institute. Non-Profit Corporation. NCI Thesaurus. Code C133311.

Special type of corporation that has been organized to meet specific tax-exempt purposes. To qualify for nonprofit status, the corporation must be formed to benefit: (1) the public, (2) a specific group of individuals, or (3) the membership of the nonprofit. 